\title{
Pretreatment with Cry1Ac Protoxin Modulates the Immune Response, and Increases the Survival of Plasmodium-Infected CBA/Ca Mice
}

\author{
Martha Legorreta-Herrera, ${ }^{1}$ Rodrigo Oviedo Meza, ${ }^{1}$ and Leticia Moreno-Fierros ${ }^{2}$ \\ ${ }^{1}$ Laboratorio de Inmunología Molecular, Facultad de Estudios Superiores Zaragoza, Universidad Nacional Autónoma \\ de México, Batalla 5 de mayo esq. Fuerte de Loreto, Iztapalapa 09230, Mexico \\ 2 Inmunidad en Mucosas UBIMED, FES-Iztacala, Universidad Nacional Autónoma de México, Avenida de los Barrios 1, \\ Los Reyes Iztacala, Tlalnepantla 54090, Mexico \\ Correspondence should be addressed to Martha Legorreta-Herrera, marthal@servidor.unam.mx
}

Received 11 August 2009; Revised 24 November 2009; Accepted 16 December 2009

Academic Editor: Luis I. Terrazas

Copyright ( $) 2010$ Martha Legorreta-Herrera et al. This is an open access article distributed under the Creative Commons Attribution License, which permits unrestricted use, distribution, and reproduction in any medium, provided the original work is properly cited.

\begin{abstract}
Malaria is a major global health problem that kills 1-2 million people each year. Despite exhaustive research, naturally acquired immunity is poorly understood. CrylA proteins are potent immunogens with adjuvant properties and are able to induce strong cellular and humoral responses. In fact, it has been shown that administration of Cry1Ac protoxin alone or with amoebic lysates induces protection against the lethal infection caused by the protozoa Naegleria fowleri. In this work, we studied whether Cry1Ac is able to activate the innate immune response to induce protection against Plasmodium berghei ANKA (lethal) and P. chabaudi AS (nonlethal) parasites in CBA/Ca mice. Treatment with CrylAc induced protection against both Plasmodium species in terms of reduced parasitaemia, longer survival time, modulation of pro- and anti-inflammatory cytokines, and increased levels of specific antibodies against Plasmodium. Understanding how to boost innate immunity to Plasmodium infection should lead to immunologically based intervention strategies.
\end{abstract}

\section{Introduction}

Each year, malaria infects approximately 500 million people and kills one to two million people, mainly children below the age of five years [1]. Despite decades of research on the subject, naturally acquired immunity to Plasmodium is still poorly understood [2-4]. There are reports about the immunosuppressive effects of Plasmodium infection in humans [5] and in animal models [6]. It is believed that the initial interaction of the parasitised red blood cells with the host immune system is one of the most important factors in determining the nature of the subsequent innate and acquired response, and in determining whether or not severe pathology, such as cerebral malaria, severe anaemia, or cachexia, results [7-9].

On the other hand, insecticidal proteinaceous crystals called Cry proteins are produced as protoxins by Bacillus thuringiensis (Bt) during sporulation. Upon ingestion, crystalline protoxins are solubilised and proteolytically activated by midgut proteases of susceptible insects. The activated toxin, which is not toxic to vertebrates, binds to specific receptors on the brush-border membrane surface of the midgut epithelium of the insect, inducing the formation of pores and eventually leading to insect mortality [10]. In particular, CrylAc is a pore-forming protein that is specifically toxic to lepidopteran insect larvae and acts by binding to the cell-surface receptor aminopeptidase $\mathrm{N}$ in the Manduca sexta midgut via the sugar N-acetyl-Dgalactosamine (GalNAc) [11, 12].

Although most studies on Cry proteins have been performed with regard to their toxicity in insects, we have described that recombinant CrylAc protoxin from Bacillus thuringiensis is a potent mucosal and systemic immunogen with adjuvant properties $[13,14]$. 
In addition, we have shown that recombinant CrylA toxins possess the ability to induce serum and mucosal specific antibody responses as well as to modulate IgG subclasses due to their strong immunogenic properties [14, 15]. Furthermore, it has been demonstrated that Cry proteins from $B$. thuringiensis can induce strong cellular immune responses. In particular, we have described that these toxins are able to promote IFN- $\gamma$ responses [16]. In malaria infections, an initial IFN- $\gamma$ response, mainly produced by NK cells, is implicated in the activation of macrophages, which leads to parasite elimination $[17,18]$. In a previous study, we found that administration of the immunogenic protein with adjuvant properties, CrylAc protoxin alone or with amoebic lysates, markedly increased protective immunity against experimental $N$. fowleri meningoencephalitis in mice [13]. In this work, we determined the ability of Cry1Ac protoxin to activate the innate immune response. So we tested whether the pretreatment with the protein alone improved the resistance of mice to Plasmodium chabaudi AS and $P$. berghei ANKA experimental infections.

\section{Materials and Methods}

2.1. Mice and Parasites. CBA/Ca mice were kindly donated by Dr. W Jarra (National Institute for Medical Research, London). The mice were bred, fed, and maintained in a specific, pathogen-free environment at the FES Zaragoza, Universidad Nacional Autónoma de México animal house facility in accordance with the institutional and national official guideline NOM-062-ZOO-1999 for use and care of laboratory animals.

P. chabaudi AS and P. berghei ANKA were donated by Dr. William Jarra (National Institute for Medical Research, London).

2.2. Infection and Treatment. Batches of 6 to 8 sex- and agematched (6-8 weeks) CBA/Ca mice were treated weekly with CrylAc protoxin ( $5 \mu \mathrm{g} /$ mouse i.p.) or with vehicle (PBS) during four weeks. One day after the last treatment, mice were inoculated intravenously with either $5 \times 10^{4} \mathrm{P}$. chabaudi AS- or $5 \times 10^{4} \mathrm{P}$. berghei ANKA-parasitised erythrocytes. On the days indicated, mice were sacrificed under ether anaesthesia. As controls, a parallel batch of noninfected mice was divided into two groups and treated with PBS or Cry1Ac at the same dose. Data presented are representative of two separate experiments.

2.3. Blood Sampling. Parasitaemias were evaluated daily by examination of Giemsa-stained blood smears. Numeration of the parasitaemia was performed under oil, using a Zeiss Standard 20 microscope (Carl Zeiss Ltd., Welwyn Garden City). Parasitaemias of $0.5 \%$ and above were determined by counting the number of parasitised erythrocytes present in a total of 200 red blood cells. Lower levels of parasitaemia were assessed by counting the number of parasitised erythrocytes present in 50 fields. The course of infection in each group is shown as the geometric mean of the percentage of parasitaemia.
2.4. Recombinant Cry1Ac Escherichia coli JM103 (pOS9300). The recombinant Cry1Ac E. coli JM103 (pOS9300) strain was kindly donated by Dr. Dean, from Ohio State University. The bacteria were grown in Luria-Bertani medium containing $50 \mu \mathrm{g} / \mathrm{mL}$ of ampicillin, and CrylAc production was induced with $1 \mathrm{mM}$ isopropyl- $\beta$-D-thiogalactopyranoside (IPTG) [19]. Recombinant CrylAc was purified from the IPTG-induced E. coli JM103 (pOS9300) cultures as follows. Cell pellets harvested by centrifugation were suspended in $50 \mathrm{mM}$ Tris-HCl, $50 \mathrm{mM}$ EDTA ( $\mathrm{pH}$ 8) (TE buffer) and sonicated (Fisher Sonic Dismembrator Model 300) three times for 5 minutes on ice. Inclusion bodies were collected by centrifugation at $10000 \times \mathrm{g}$ for 10 minutes, and pellets were washed twice with TE buffer, twice with $0.5 \mathrm{M} \mathrm{NaCl}$, and once with $0.5 \mathrm{M} / \mathrm{NaCl}-1 \%$ Triton $\mathrm{X}-100$, once with $0.5 \mathrm{M} \mathrm{NaCl}$, once with cold distilled water and were finally solubilised in CBP buffer $\left(0.1 \mathrm{M} \mathrm{Na} \mathrm{CO}_{3}\right.$, 1\% 2-mercaptoethanol [ $\mathrm{pH} 9.6])$. Particulate material was discarded by centrifugation at $10000 \times \mathrm{g}$ for $10 \mathrm{~min}$, and the purified solubilised protoxin was stored at $4^{\circ} \mathrm{C}$ and examined by sodium dodecyl sulphate-polyacrylamide gel electrophoresis (SDS-PAGE). The protein concentration was determined using the Bradford method [20]. The presence of endotoxin contamination in the Cry1Ac protoxin preparations was tested using the E-toxate, Part 1 kit (Sigma), which has a sensitivity limit of $0.05-0.1$ endotoxin units $(\mathrm{EU}) / \mathrm{mL}$, following the manufacturer's instructions. Endotoxin levels in the purified CrylAc protoxin preparations were below $0.1 \mathrm{EU} / \mathrm{mL}$. These preparations were further treated with an excess of a polymyxin B resin (Bio-Rad, Hercules CA, USA) to remove any possible remnants of endotoxin.

2.5. Cytokine mRNA Expression. Groups of CBA/Ca mice were treated weekly with Cry1Ac protoxin or with PBS for four weeks. Twenty-four hours after the last inoculation, mice were infected with either $P$. chabaudi AS or P. berghei ANKA. On the days indicated, three mice of each group were sacrificed under ether anaesthesia, and spleen mRNA was extracted using Trizol (Invitrogen, Carlsbad, CA, USA). DNA was digested with DNase I (Invitrogen) according to the manufacturer's instructions, and RNA was quantified spectrophotometrically at $260 \mathrm{~nm}$. Next, $1.5 \mu \mathrm{g}$ of RNA were retrotranscribed using $1.5 \mu \mathrm{g}$ of oligo dT (Invitrogen), $0.5 \mathrm{mM}$ dNTPs (Pharmacia, Uppsala, Sweden), 40 U RNase inhibitor, and $200 \mathrm{U}$ MMLV-RT (Invitrogen). Next, $1 \mu \mathrm{L}$ of the resulting CDNA was used to amplify IFN- $\gamma$ and TGF$\beta$ by PCR. Each sample was amplified in duplicate using a previously described method [21].

Each set of primers as well as the cDNA concentration was optimized for a number of cycles to obtain amplicons in the linear phase of amplification. The following genespecific primer sequences were used: (IFN- $\gamma$ ) forward: $5^{\prime}$ TGC ATC TTG GCT TTG CAG CTC TTC CTC ATG GC 3', reverse 5' TGG ACC TGT GGG TTG TTG ACC TCA TTG GC $3^{\prime}$; (TGF- $\beta$ ) forward $5^{\prime}$ GAC CGC AAC AAC GCC ATC TA $3^{\prime}$ reverse $5^{\prime}$ GGC GTA TCA GTG GGG GTC AG 3'; ( $\beta$-actin) forward 5' GTG GGC CGC TCT AGG CAC CAA $3^{\prime}$, reverse $5^{\prime}$ CTC TTT GAT GTC ACG 
CAC GAT TTC 3'. PCR reactions were performed in a total volume of $20 \mu \mathrm{L}$. Amplification was carried out in $50 \mathrm{mM}$ $\mathrm{KCl}, 10 \mathrm{mM}$ Tris- $\mathrm{HCl}$ (pH 8.3), $0.1 \mathrm{mg} / \mathrm{mL}$ gelatin, $200 \mathrm{mM}$ of each dNTP, $2 \mathrm{mM} \mathrm{MgCl}_{2}, 100 \mathrm{nM}$ of each primer, $0.5 \mathrm{U}$ Ampli Taq polymerase (Applied Biosystems, Branchburg, NJ, USA), and 15 ng of cDNA. The $\beta$-actin gene and either IFN$\gamma$ or TGF- $\beta$ were then simultaneously amplified in a single tube. After 27-29 cycles, the PCR products were separated on $5 \%$ polyacrylamide gels and stained with ethidium bromide. Each band was analysed by densitometry, and the results are shown as the relation of the absorbance of the corresponding cytokine to that of $\beta$-actin in the same sample.

2.6. Cytokine Serum Measurement. On days indicated, mice from both the $P$ chabaudi AS- and the P. berghei ANKAinfected groups were sacrificed under ether anaesthesia. Immediately, blood from the heart was extracted and then centrifuged at $2000 \times \mathrm{g}$ at $4^{\circ} \mathrm{C}$ for $15 \mathrm{~min}$. The serum was removed and aliquoted into two tubes and snap frozen at $-70^{\circ} \mathrm{C}$ until used.

The levels of the cytokines interleukin-2 (IL-2), interleukin-4 (IL-4), interleukin-5 (IL-5), interferon- $\gamma$ $($ IFN- $\gamma$ ), and tumour necrosis factor- (TNF- $\alpha$ ) in the serum samples were measured using a cytometric bead array performed according to the manufacturer's instructions (BD Mouse Th1/Th2 Cytokine CBA Kit Biosciences-Pharmingen, Heidelberg, Germany) with the following modifications. We performed all steps in microtubes, and we started the standard curve at a concentration of $0.625 \mathrm{pg} / \mathrm{mL}$. The sensitivity achieved with these minor adaptations to the protocol was $0.9 \pm 0.05 \mathrm{pg} / \mathrm{mL}$ while the variation inter-assay was approximately $5 \%$.

2.7. Measurement of Protective Antibodies. Antibody-specific responses were evaluated using a previously described method [21].

A lysate of pRBC was used as the capture antigen; it was prepared as follows. P. chabaudi AS- or P. berghei ANKAinfected mice (25\% parasitaemia) were bled into PBSheparin at $4{ }^{\circ} \mathrm{C}$ to provide parasitised erythrocytes. The blood was passed through a CF11 cellulose powder (Whatman, Maidstone, UK) column to remove leukocytes and then washed three times with PBS by centrifugation at $750 \times \mathrm{g}$ for $15 \mathrm{~min}$ at $4^{\circ} \mathrm{C}$. The final cell pellet was resuspended to $5 \mathrm{~mL}$ in PBS, and $3 \mu \mathrm{L}$ of $10 \%(\mathrm{w} / \mathrm{v})$ saponin in PBS was added to lyse the erythrocyte membranes. After centrifugation at $18,000 \times \mathrm{g}$ for $5 \mathrm{~min}$ at $4^{\circ} \mathrm{C}$, the supernatant was removed, the pellets were resuspended to $3 \mathrm{~mL}$ in $\mathrm{PBS}$, and the cells were lysed by ultrasonication for 3 seconds with $21 \%$ amplitude (Ultrasonic Processor Model GE750, USA). The protein concentration of the lysates was determined using a Bio-Rad commercial reagent, and the lysate was diluted in carbonate-buffered solution to give a coating concentration of $10 \mu \mathrm{g} / \mathrm{mL}$. A volume of $100 \mu \mathrm{L} /$ well was applied to flatbottomed 96-well ELISA plates (Corning USA). First, the plates were washed with $0.05 \%(\mathrm{v} / \mathrm{v})$ Tween 20 in PBS, and then the excess binding sites were blocked using a solution of $3 \%$ skim milk in PBS for 2 hours at $37^{\circ} \mathrm{C}$. The plates were then incubated with test sera in duplicate for $1 \mathrm{~h}$ at $37^{\circ} \mathrm{C}$ and diluted to $1 / 20$ in PBS. Plates were washed extensively before detection of parasite-specific Abs using goat antimouse horseradish peroxidase-conjugated monoclonal Abs $(\mathrm{mAb})$ specific to IgG1, IgG2a, IgG2b, IgG3, total IgG, or IgM (Zymed, San Francisco California, USA) diluted in 0.02\% skim milk, $0.05 \%$ Tween 20 in PBS to previously calibrated dilutions, which were applied to plates for $1 \mathrm{~h}$ at $37^{\circ} \mathrm{C}$. Plates were washed before incubation with a streptavidin peroxidase solution (diluted $1: 3000$ in $0.05 \%$ Tween 20 in PBS) before the final wash. Plates were developed with ortho phenylenediamine at $0.4 \mathrm{mg} / \mathrm{mL}$ in citrate buffer $(\mathrm{pH}$ 5) with $0.03 \%$ of hydrogen peroxide as a substrate and incubated in the dark at room temperature for $20 \mathrm{~min}$. Absorbance was determined at $492 \mathrm{~nm}$ by measurement of optical density (OD) using a Stat-Fax 2100 microplate reader (Awareness Technology Inc, USA). No standard of known concentration for each Ig isotype was available. Hence results were expressed directly as OD $492 \mathrm{~nm}$ values and compared to an internal standard of normal CBA mouse serum obtained from eight- to ten-week-old naive female mice. This internal standard provided a background value of nonspecific responsiveness to the lysate used.

2.8. Statistical Analysis. Statistical analysis was performed with the Stat Graphs software (version 5.1). Differences between groups were tested for statistical significance by nonparametric analysis of variance (Kruskal-Wallis). A $P$ value $<.05$ was considered significant. All data are expressed as the mean \pm S.D. Each experiment was performed in duplicate.

\section{Results}

3.1. CrylAc Treatment Decreases Parasitaemia in $C B A / C a$ Mice Infected with Plasmodium chabaudi AS or P. berghei ANKA. Groups of CBA/Ca mice were injected once weekly for four weeks with CrylAc protoxin or PBS as described in the Materials and Methods. One day after the last injection, mice were intravenously infected either with $P$. chabaudi AS or with $P$. berghei ANKA. Mice treated with CrylAc protoxin prior to $P$. chabaudi AS infection developed a moderate parasitaemia that increased from day 6 postinfection (PI) to reach a peak of $27 \%$ at day 10 PI. Parasitaemia resolved spontaneously and was cleared by day 15 PI. In contrast, control mice treated with vehicle (PBS) developed higher parasitaemias from day 6 to 15 PI (significantly $(P<.05)$ from days 8 to $11 \mathrm{PI}$ ) compared to mice treated with CrylAc protoxin. Parasitaemia reached a peak of $40 \%$ at day 10 , and the parasite was completely cleared at day $16 \mathrm{PI}$, one day later than in the group of mice treated with CrylAc (Figure 1(a)).

In contrast, infection with $P$. berghei ANKA was lethal. In control $\mathrm{CBA} / \mathrm{Ca}$ mice treated with vehicle (PBS), parasitaemia increased from day 5 PI to reach a peak of $23 \%$ at day 8 PI. There was a slight decrease in parasitaemia at day 9 , and then mice started to die on day 10 PI with parasitaemias around $20 \%$, confirming the reported lethality of this strain $[22,23]$. Infected mice previously treated with 


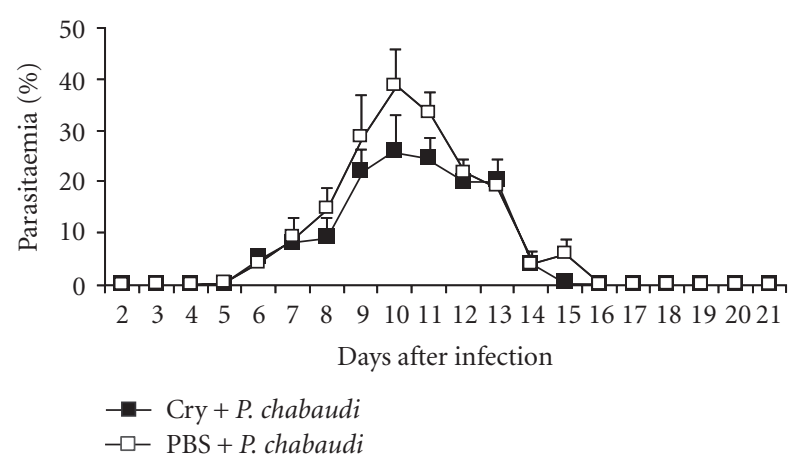

(a)

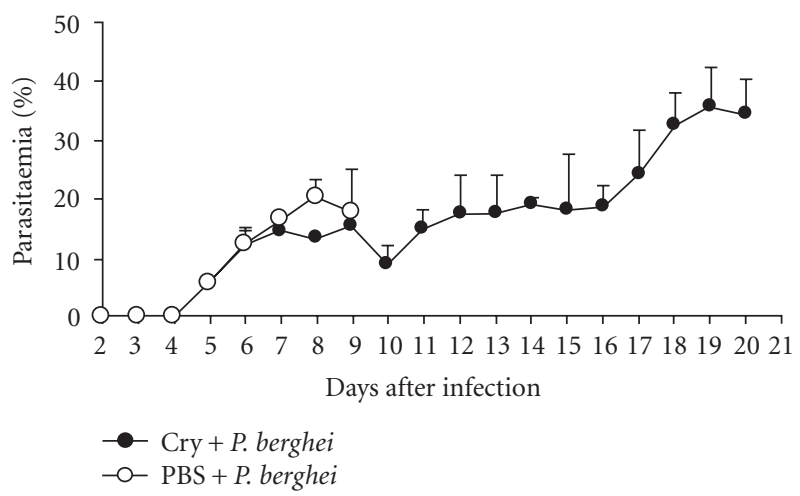

(b)

Figure 1: Effect of CrylAc on parasitaemia in CBA/Ca mice. Groups of eight mice were treated with Cry1Ac protoxin once a week for four weeks. One day after the last injection, mice were infected with $P$. chabaudi AS (a) or P. berghei ANKA (b). Groups of control mice were treated with PBS. Data are representative of two separate experiments.

the protoxin CrylAc developed lower levels of parasitaemia than PBS-treated mice from days 7 to 9 PI; the number of parasites in their blood decreased on day 10 PI and then started to rise slowly. Half of this group of mice survived until day 20 PI with parasitaemias of approximately $40 \%$ (Figures 1(b) and 2).

3.2. Cry1Ac Protoxin Increases Survival in PlasmodiumInfected Mice. Despite the fact that Plasmodium chabaudi AS is not considered to be lethal, infection with this parasite could be fatal for $10 \%$ to $20 \%$ of CBA/Ca mice. Interestingly, mice treated with CrylAc and infected with $P$. chabaudi AS had a survival rate of $100 \%$ compared to mice treated with PBS, which had a survival rate of $80 \%$. On the other hand, mice treated with CrylAc and infected with the lethal parasite P. berghei ANKA showed an increased survival of 12 days compared to control mice treated with PBS, which died at day 9 PI (Figure 2).

3.3. Cry1Ac Protoxin Modulates Cytokine mRNA Expression in Splenocytes from Malaria-Infected Mice. RT-PCR analysis was performed to determine the levels of cytokine mRNA expression in splenocytes from infected and uninfected mice.

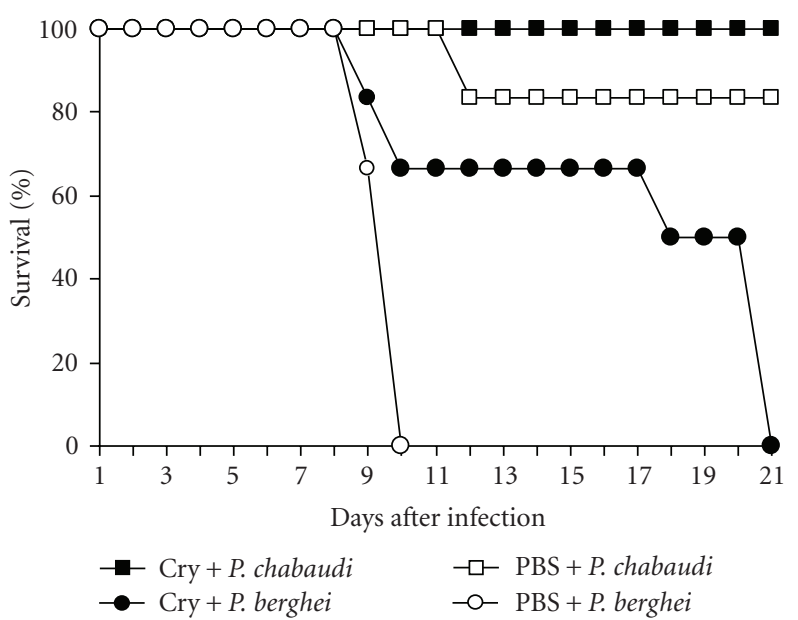

Figure 2: Effect of CrylAc on the survival of Plasmodium-infected mice. CrylAc pretreated mice $(n=8)$ were infected with $P$. chabaudi AS or P. berghei ANKA. Survival was recorded until day $21 \mathrm{PI}$, at which time all of the P. berghei ANKA-infected mice had died. Data are representative of two separate experiments.

Cells were obtained at days 4 and 8 PI with $P$. berghei ANKA and at days 8 and 18 PI with P. chabaudi AS. The levels of cytokine mRNA expression were normalised to $\beta$ actin mRNA levels, which was used as an internal standard. Moderate, constitutive mRNA expression of IFN- $\gamma$ and TGF$\beta$ was detected in control mice receiving the vehicle, while in uninfected mice treated with CrylAc, similar levels of these cytokines were recorded (Figure 3).

In $P$. berghei ANKA-infected mice that previously had been administered CrylAc protoxin, increased levels of IFN$\gamma$ mRNA expression were detected at days 4 and 8 PI compared to infected mice receiving just the vehicle or uninfected mice. At day 4 PI, similar levels of TGF- $\beta$ were found in both infected groups (slightly higher than those in uninfected mice). In contrast, at day $8 \mathrm{PI}$, the levels of TGF$\beta \mathrm{mRNA}$ were lower in mice pretreated with Cry1Ac protoxin than in those receiving just the vehicle (Figures 3(a) and $3(\mathrm{c})$ ).

In control mice infected with $P$. chabaudi AS, the levels of IFN- $\gamma$ mRNA at days 8 and 18 PI were higher than those in mice pretreated with CrylAc protoxin, which exhibited IFN- $\gamma$ levels akin to those in uninfected mice. On the other hand, the mRNA levels of TGF- $\beta$ recorded in $P$. chabaudi ASinfected mice did not change significantly either by infection or by pretreatment with CrylAc protoxin.

3.4. Cry1Ac Modifies Cytokine Levels in Sera from Plasmodium-Infected Mice. The levels of cytokines (IFN- $\gamma$ and IL-4) in serum samples were measured with a cytometric bead array. Samples were obtained at days 4 and 8 or 8 and 18 postinfection with $P$. berghei ANKA and P. chabaudi AS, respectively.

The levels of IFN- $\gamma$ were significantly increased at day 8 PI with P. berghei ANKA in mice pretreated with CrylAc, confirming the RT-PCR results. At day 4 postchallenge, 


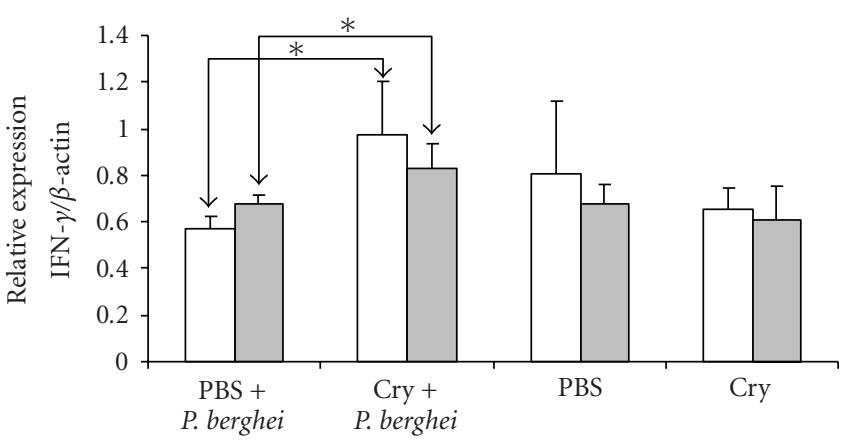

(a)

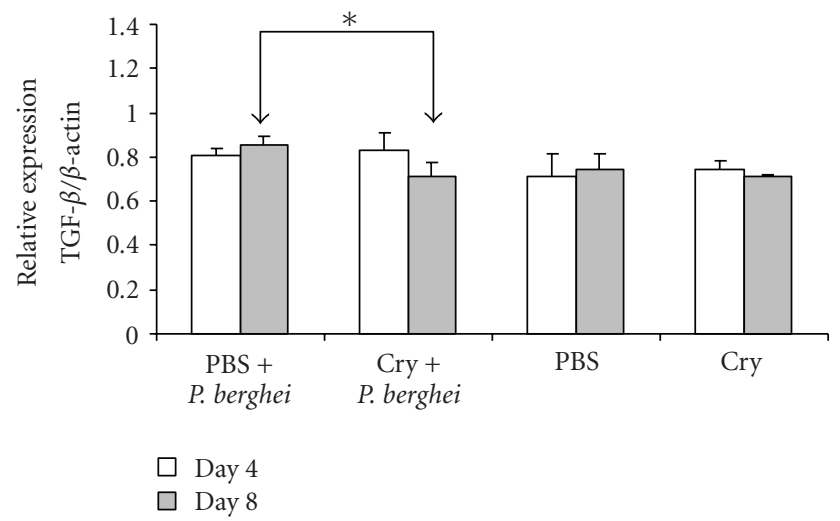

(c)

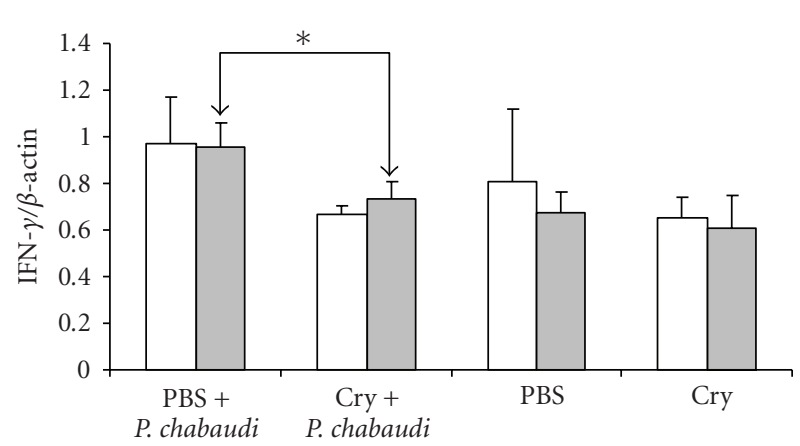

(b)

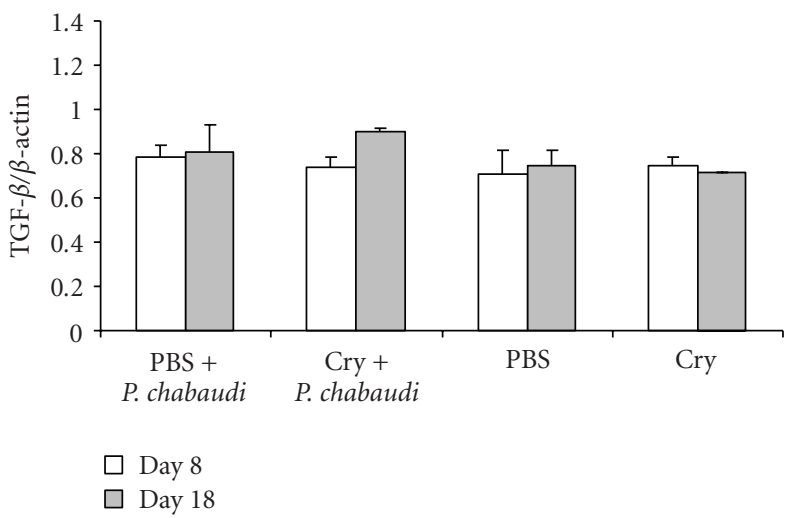

(d)

FIGURE 3: Effect of CrylAc on the mRNA expression of IFN- $\gamma$ (a and b) and TGF- $\beta$ (c and d) in mice infected with $P$. chabaudi AS or $P$. berghei ANKA. Mice were treated with CrylAc protoxin or PBS as a control. One day after the last injection, mice were infected with $P$. berghei ANKA or P. chabaudi AS. On days 4 and 8 PI (a and c) or days 8 and 18 PI (b and d), three mice from each group were killed, and their splenic mRNA was extracted and retrotranscribed. The cDNA obtained was used to amplify the $\beta$-actin gene and either IFN- $\gamma$ or TGF- $\beta$ by PCR in the same tube. PCR products were separated on 5\% polyacrylamide gels. Bands were analysed by densitometry, and the results are shown as the absorbance of the corresponding cytokine divided by the absorbance of $\beta$-actin. Data are representative of two separate experiments. Asterisks indicate statistically significant differences between the indicated groups.

the IFN- $\gamma$ mRNA levels recorded were low and akin to infected control mice, although they are greater than the levels in uninfected control mice. The levels of IL-4 were also low and did not vary significantly as a result of infection with P. berghei ANKA or administration of CrylAc protein (Figure 4). In contrast, following infection with P. chabaudi AS, the levels of IFN- $\gamma$ were higher in control mice than in those pretreated with CrylAc protoxin. The IFN- $\gamma$ levels induced after $P$. chabaudi AS infection were considerably lower compared to those elicited following P. berghei ANKA infection, but they were still higher than those present in uninfected mice.

In control P. chabaudi AS-infected mice, the levels of IL-4 increased at day $18 \mathrm{PI}$, while in mice pretreated with CrylAc, the levels of this cytokine did not change (Figure 4). Levels of IL-2, IL- 5 and TNF- $\alpha$ were not modified by any of these treatments (results not shown).

3.5. Protoxin CrylAc Increases the Levels of Specific Antibodies for P. berghei ANKA and P. chabaudi AS in Infected Mice. Specific anti-P. berghei ANKA antibodies were induced in sera from mice infected with the parasite (at days 4 and 8
PI), while sera from control uninfected mice, which were untreated or received PBS or CrylAc alone, did not have detectable anti-P.berghei ANKA antibodies (Figure 5).

The treatment with protoxin CrylAc before infection increased the levels of IgG1, IgG2a, IgG2b, and IgM in $P$. berghei ANKA-infected mice. Interestingly, this increase was only detected on day 4 PI compared to mice receiving the vehicle alone. At day $8 \mathrm{PI}$, similar levels of IgG and IgM responses were induced in both experimental groups (Figure 5).

In infected mice pretreated with CrylAc, the specific anti-P. chabaudi AS IgG response was significantly higher on days 8 and 18 than that elicited in infected mice pretreated with the vehicle (Figure 6). Regarding the analyses of the different IgG subclasses, specific responses at day 4 PI of the four IgG subclasses (IgG1, IgG2a, IgG2b, and IgG3) were also significantly higher in the group receiving CrylAc before the infection compared to the group receiving the vehicle alone (Figure 5). However, at day $8 \mathrm{PI}$, the IgG2b responses detected were higher in the vehicle group with respect to the CrylAc group, while the IgG responses of the rest of the isotypes recorded were similar between the two groups. 


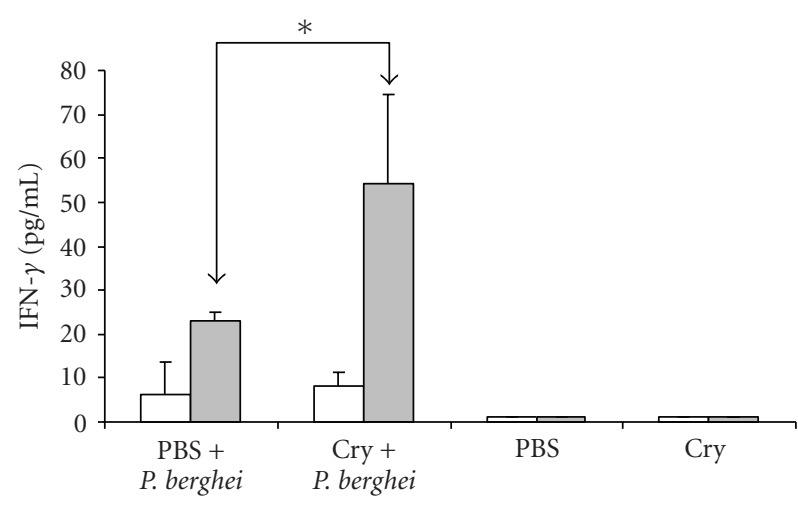

(a)

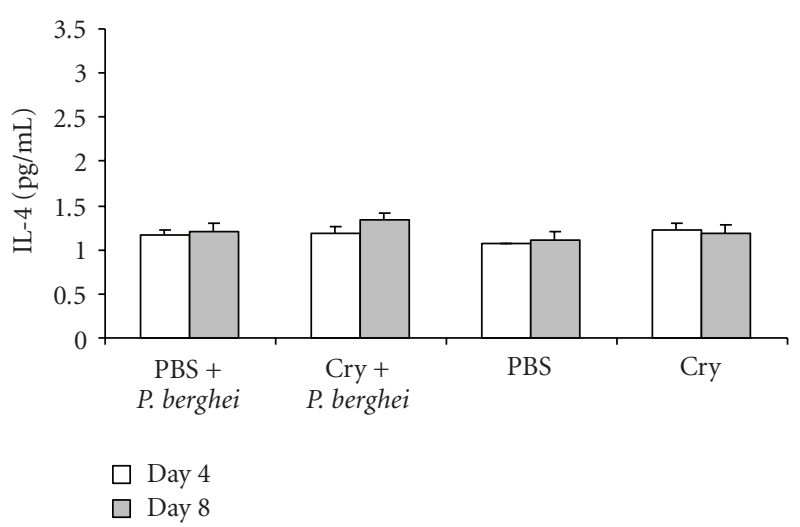

(c)

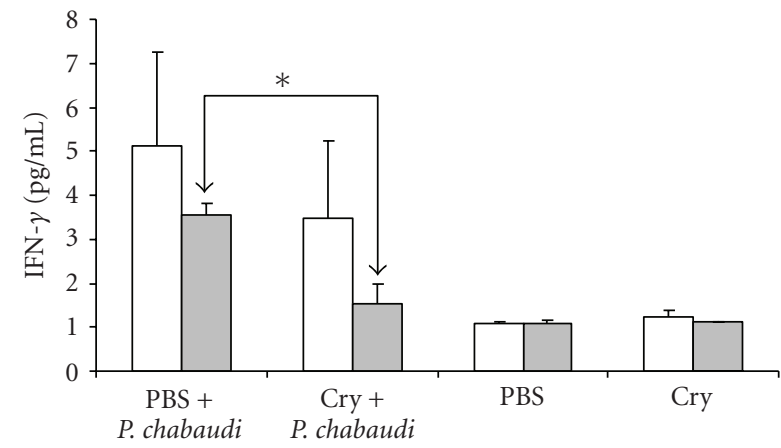

(b)

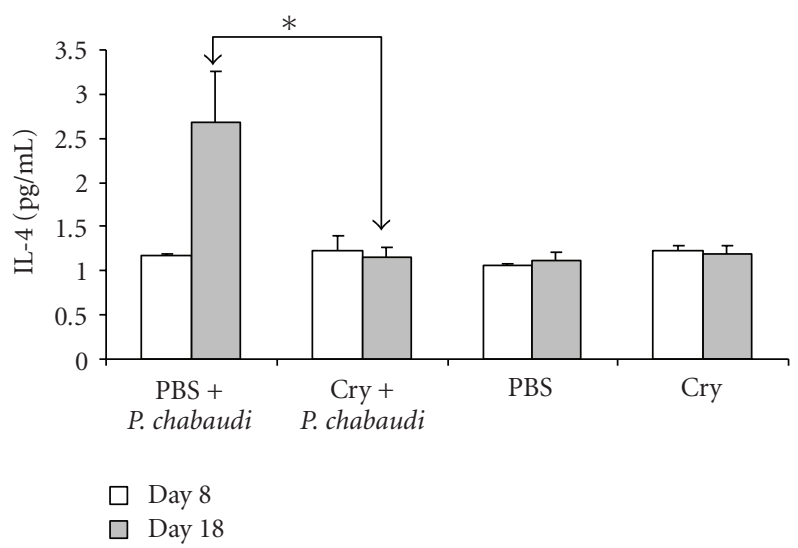

(d)

Figure 4: Effect of Cry1Ac on serum cytokines in Plasmodium-infected mice.Mice were treated with CrylAc protoxin or PBS once weekly for four weeks. One day after the last injection, mice were infected with P. berghei ANKA or P. chabaudi AS. On days 4 and 8 PI (a and c) or days 8 and 18 PI (b and d), three mice from each group were killed, their sera was separated from peripheral blood and the levels of the cytokines IFN- $\gamma$ ( $\mathrm{a}$ and $\mathrm{b}$ ) and IL-4 (c and d) were measured by cytometric bead array. Data are representative of two separate experiments. Asterisks indicate statistically significant differences between the indicated groups.

The IgM-specific response at day 8 PI was significantly higher in the group that received CrylAc than in the group treated with vehicle.

The specific antibody responses recorded in mice infected with $P$. berghei ANKA were lower in relation to those elicited in mice infected with $P$. chabaudi AS. This result was expected since the latter group of mice had a longer period of antigenic stimulation. In sera from uninfected mice receiving either the vehicle (PBS) or CrylAc, specific anti-P. berghei ANKA antibodies were not detected.

\section{Discussion}

Our results demonstrate that administration of the CrylAc protoxin from $B$. thuringiensis induces protection against the malaria parasite when it is administered in CBA/Ca mice before infection with $P$. chabaudi AS and induces a longer survival time in $P$. berghei ANKA-infected mice (Figures 1 and 2). Protection was shown by lower levels of parasitaemia (first peak) in groups of mice infected with either P. chabaudi AS or P. berghei ANKA compared to control mice. In addition, CrylAc protoxin modulated the mRNA expression of proinflammatory cytokines, such as IFN- $\gamma$ and TGF- $\beta$, and increased the levels of IgG and IgM in both P. berghei ANKA- and P. chabaudi AS-infected mice.

Due to the different courses of parasitaemia between $\mathrm{CBA} / \mathrm{Ca}$ mice infected with the lethal P. berghei ANKA, which killed all of the mice around day 9 PI, and the non-lethal $P$. chabaudi AS, the samples were analysed at different days ( 4 and 8 versus 8 and 18, resp.) to get the best comparison between both infections.

We evaluated the effect of CrylAc protoxin against Plasmodium infection because we have previously described that this protein may be a valuable tool for the improvement of mucosal vaccines; when CrylAc protoxin is coadministered as an adjuvant, it increases protective immunity against experimental Naegleria fowleri meningoencephalitis, an acute fulminant infection initiated at the nasal mucosa, in mice [13]. Interestingly, intranasal administration of CrylAc alone also had protective effects against $N$. fowleri infection, as this treatment increased 


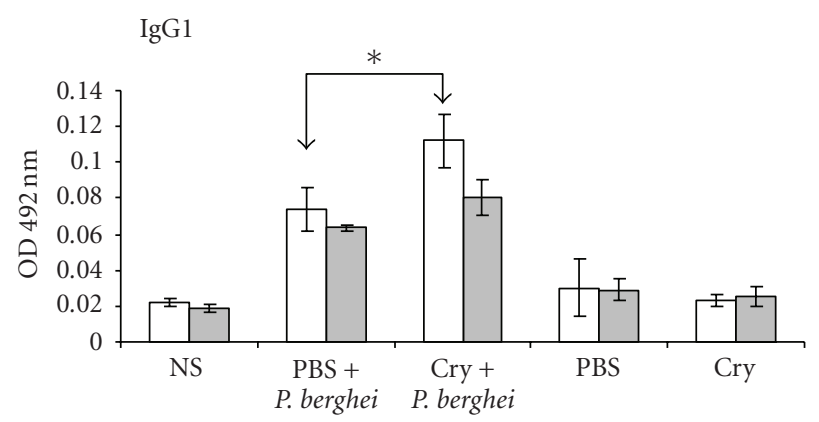

(a)

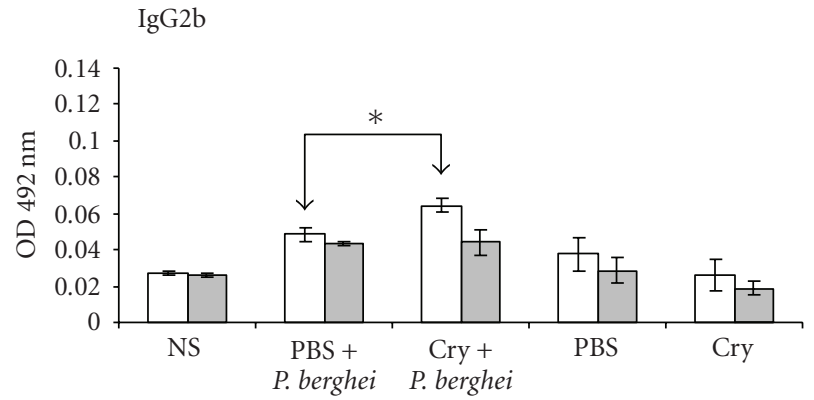

(c)

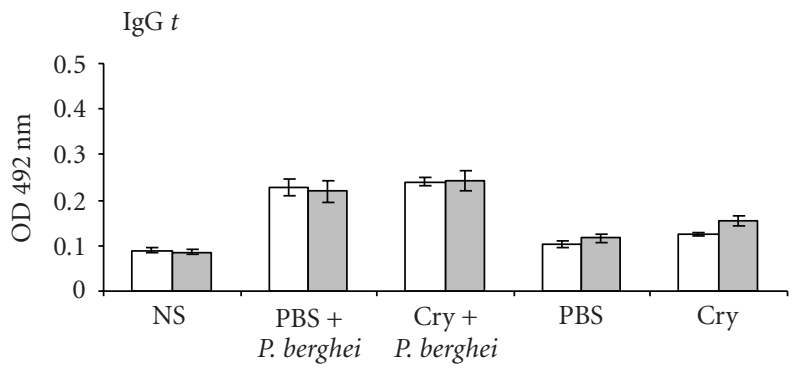

(e)

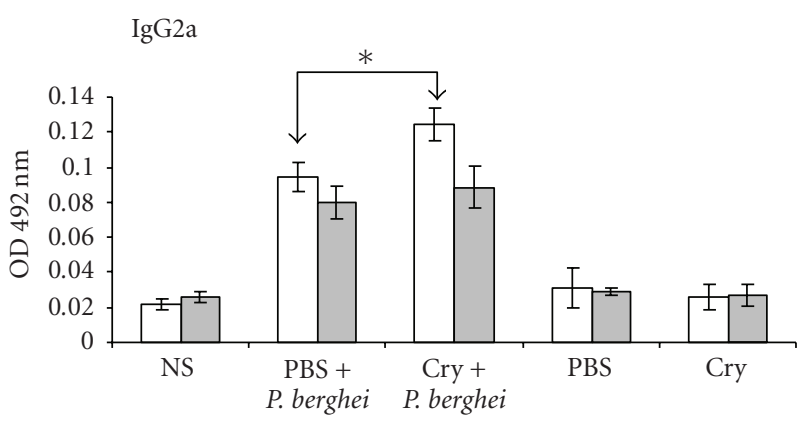

(b)

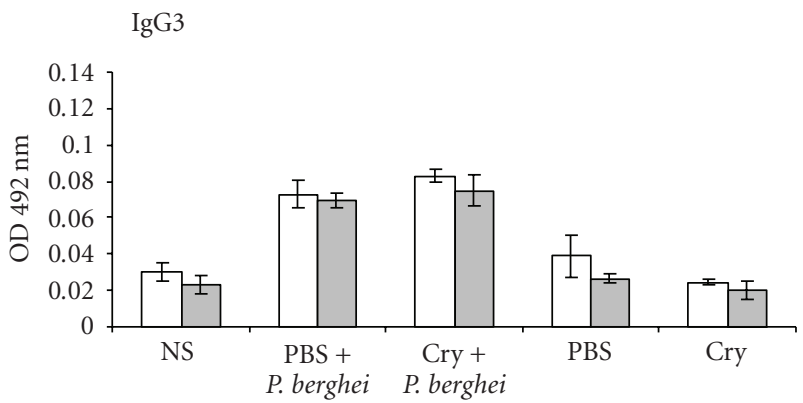

(d)

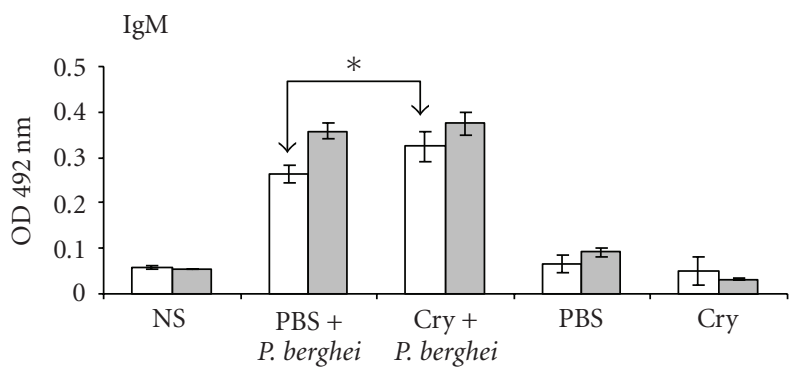

(f)

FIgure 5: Parasite-specific antibody responses in mice treated with CrylAc and infected with $P$. berghei ANKA. Mice were treated with CrylAc protoxin or PBS as described previously and were infected with P. berghei ANKA. At days 4 (white bars) and 8 (grey bars) PI, the sera of three mice from each group were collected and measured by ELISA for antibody levels. The results are expressed as the mean OD value $\pm \mathrm{SD}(n=3)$. Control absorbance values were provided by normal mouse serum (NS) obtained from age- and sex-matched CBA/Ca mice. Data are representative of two separate experiments. Asterisks indicate statistically significant differences between the indicated groups.

survival, as immunization with amoebal lysates alone did, suggesting that CrylAc protoxin may boost innate immunity.

In addition, it has been reported that CrylAc protoxin enhances the respiratory burst of human monocytes and neutrophils [24]. Accordingly, our unpublished results suggest that CrylAc activates mouse macrophages, inducing the expression of the costimulatory molecules B7-1 and B7-2 and the production of some proinflammatory cytokines (IFN- $\gamma$ and MCP-1), but further studies are required to elucidate the mechanisms involved.

Despite the fact that Cry proteins are not toxic to vertebrates and CrylAc is known to form pores exclusively in the midgut epithelial cells of lepidopteran insect, the existence of an unknown receptor in mammals has been suggested, because CrylAc protoxin binds to brush border membrane vesicles prepared from mouse small intestine in vitro [14]. The nature of the molecules interacting with Cry proteins in mammalian enterocytes seems to be different than the receptor glycoproteins described in insects, such as the $120-\mathrm{kDa}$ aminopeptidase $\mathrm{N}[11]$ and the $210-\mathrm{kDa}$ cadherin-like glycoprotein (Bt-R1) [25] because binding to its receptor was not inhibited by GalNAc, mannose, or biotin.

On the other hand, it has been shown that IFN$\gamma$ is able to activate macrophages, which are responsible for elimination of the the malaria parasite [26-28]. Our results show that treatment with CrylAc protoxin decreased parasitaemia in mice infected with $P$. berghei ANKA at day 8 PI. At that time, downregulation of TGF- $\beta$ expression and an increase in both mRNA expression and serum levels of IFN- $\gamma$ were found (Figures 3 and 4 ). This finding is consistent with a previous report showing that protective immunity was associated with a decrease in TGF- $\beta$ and a concomitant increase in IFN- $\gamma$ production in $P$. yoelii 17XL-infected mice [29]. In addition, it has been shown 


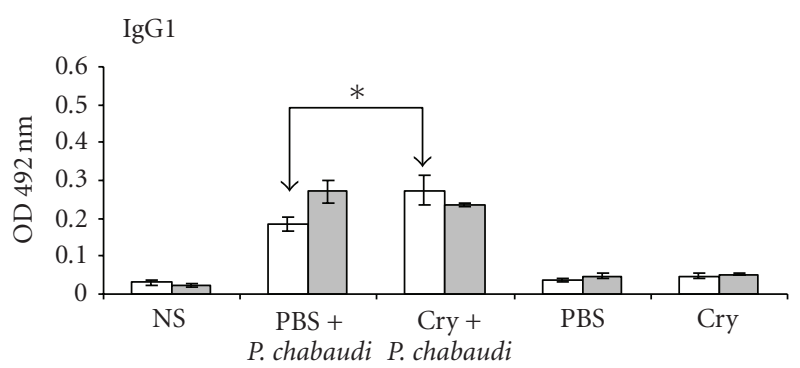

(a)

$\operatorname{IgG} 2 \mathrm{~b}$

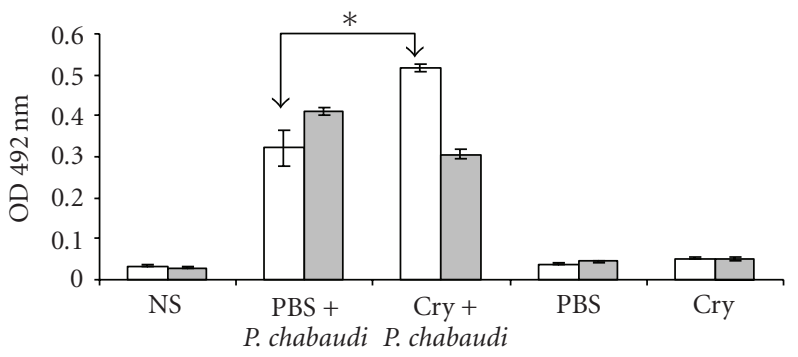

(c)

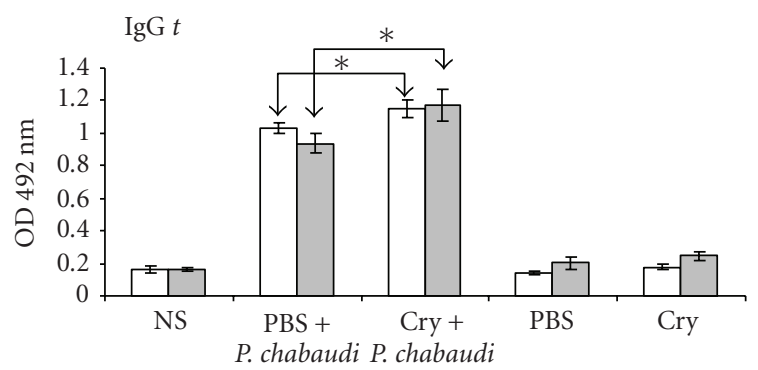

(e)

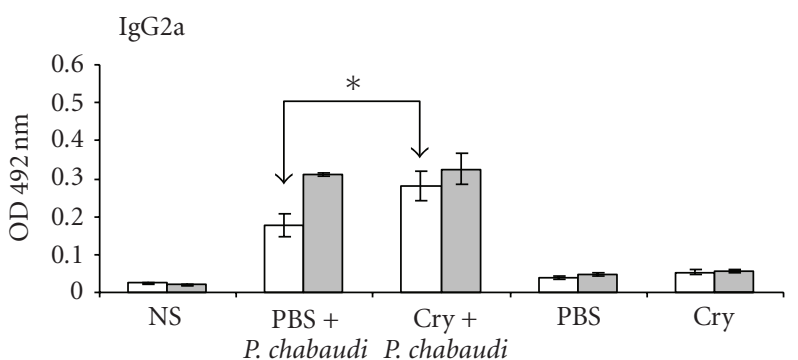

(b)

IgG3

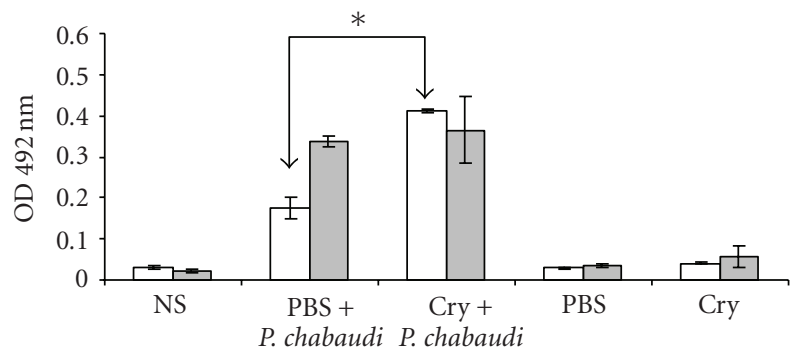

(d)

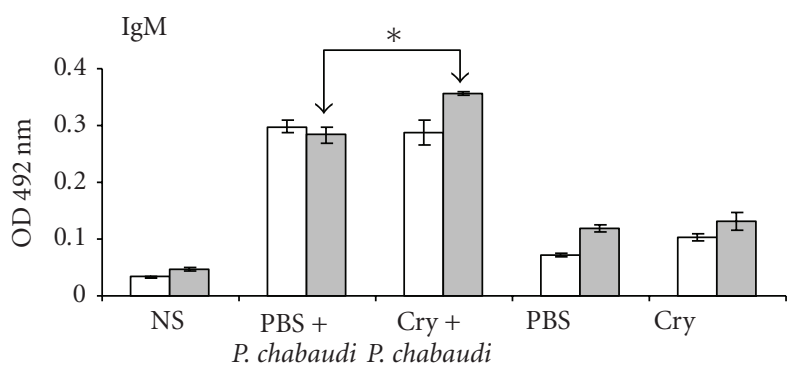

(f)

FIGURE 6: Parasite-specific antibody responses in mice treated with CrylAc and infected with P. chabaudi AS. Mice were treated with CrylAc protoxin or PBS as described previously and were infected with P. chabaudi AS. At days 8 (white bars) and 18 (grey bars) PI, the sera of three mice from each group were collected and measured by ELISA for antibody levels. The results are expressed as the mean OD value \pm SD $(n=3)$. Control absorbance values were provided by normal mouse serum (NS) obtained from age- and sex-matched CBA/Ca mice. Data are representative of two separate experiments. Asterisks indicate statistically significant differences between the indicated groups.

that upregulation of IFN- $\gamma$ in $P$. berghei ANKA-infected mice leads to the activation of macrophage, which increases parasite elimination [30]. However, mice infected with $P$. berghei ANKA in our study were not fully protected, and all of them died at day 21 PI. A possible explanation for this finding is that the effect of CrylAc protoxin is limited; it could promote a decrease in parasitaemia in mice at day 8 PI, which, in turn, diminishes the antigenic stimulation and downregulates the immunopathology. As the parasite was not completely eliminated, it started to proliferate again, and by day 11, PI Cry1Ac protoxin no longer had an effect.

On the other hand, clearance of $P$. chabaudi in mice depends first on their ability to mount an early proinflammatory cytokine response and second on their ability to downregulate the inflammatory response before the onset of the immunopathology [31]. In our study, mice treated with protoxin CrylAc and infected with $P$. chabaudi AS more efficiently eliminated parasitaemia, despite the fact that this group demonstrated a decrease in IFN- $\gamma$ mRNA expression that correlated with decreased serum levels of this cytokine compared to mice treated with PBS (Figures 3 and 4). This fact could be related to the upregulation of TGF- $\beta$, which has been shown to play a double role in malaria infections; it is able to lead pro- and anti-inflammatory responses that may downregulate the production of IFN- $\gamma$ [29]. It is also possible that the improved parasite elimination in the mice treated with CrylAc could be related to higher levels of IgG and IgM antibodies, which could be associated with better parasite elimination due to an increase in phagocytosis [32-36].

Treatment with protoxin CrylAc before Plasmodium infection induced a stronger antibody response in CBA/Ca mice to both Plasmodium berghei ANKA and P. chabaudi AS infections compared to control mice treated with PBS (Figures 5 and 6). Currently, the reason for this increase is not clear; however, this finding could be explained by a cross-reaction resulting from molecular similarities between 
epitopes of Plasmodium and the CrylAc protoxin. We have performed ELISA assays in which the CrylAc protoxin or P. berghei ANKA antigen was bound to the plate and several dilutions of $P$. berghei ANKA immune mice serum were tested. In these assays, immune sera to $P$. berghei ANKA or P. chabaudi AS recognised CrylAc protoxin and developed higher OD values compared to normal mouse serum (data not shown), strongly suggesting that $P$. berghei ANKA and CrylAc share common antigens. However, further study is required to characterise the precise antigens involved.

Another possible mechanism, in which the pretreatment with CrylAc may increase survival in Plasmodium-infected mice and may increase both the levels of Plasmodiumspecific antibodies elicited after the challenge and the levels of IFN- $\gamma$, may involve the activation of innate immune cells, such as antigen presenting cells, that permit a faster establishment of adaptive immune responses. In agreement with this proposal, our unpublished data indicate that CrylAc protoxin activates mouse macrophages, inducing the expression of the costimulatory molecules B7-1 and B7-2 and the production of proinflammatory cytokines.

The isotypes of protective antibodies in Plasmodium infections are under debate. In general, it is accepted that IgG1 and IgG2a are protective [37-40]. However, in some reports, IgG2b or IgG3 are also mentioned as being protective $[41,42]$. In mice, it is well known that IFN- $\gamma$, the principal Th1 effector cytokine, regulates the production of the opsonising or cytophilic isotype IgG2a [43], which is in accordance with our results in $P$. berghei-infected mice, and that IL-4 is central to the synthesis of IgG1, while TGF- $\beta$ is involved in the synthesis of IgG2b [38]. In our study, we found that pretreatment with CrylAc protoxin significantly increases the $\operatorname{IgG}$ subclasses assessed and IgM in P. chabaudi AS- or P. berghei ANKA-infected mice, which could be associated with parasite clearance because it has been shown that antibody responses play a critical role in immune protection against Plasmodium in asexual blood stages. This role has been demonstrated by passive transfer experiments using sera or purified immunoglobulins from adults residing in areas with hyperendemic malaria $[44,45]$. However, the mechanisms by which malaria-specific antibodies interfere with the development and/or multiplication of the asexual stages of human Plasmodia are still unclear. It has been postulated that antibodies inhibit parasite growth in cooperation either with monocytes or neutrophils via antibody-dependent cellular inhibition $[46,47]$ or by immunophagocytosis through Fc receptors expressed on the cell surface after binding their parasite target [48]. In addition, a correlation between immune protection and the ability of serum to mediate opsonisation of infected erythrocytes has been described [49]. Further studies are required to clarify the mechanisms involved in boosting the innate immunity against malaria.

Like most adjuvants CrylAc protoxin might exert its activity by activating innate immune cells. The data presented in this study suggest that pretreatment with this protein could lead to design prophylactic strategies to improve resistance against malaria infections. However, further studies are required to clarify the mechanisms involved in boosting the innate immunity against Plasmodium infection.

\section{Acknowledgments}

The authors thank Armando Cervantes for his help with the statistical analysis. This work was supported by the following Grants: PAPIIT IN214007, IN220310, IN221807, and CONACYT 080920.

\section{References}

[1] R. W. Snow, C. A. Guerra, A. M. Noor, H. Y. Myint, and S. I. Hay, "The global distribution of clinical episodes of Plasmodium falciparum malaria," Nature, vol. 434, no. 7030, pp. 214-217, 2005.

[2] P. C. Bull and K. Marsh, "The role of antibodies to Plasmodium falciparum-infected-erythrocyte surface antigens in naturally acquired immunity to malaria," Trends in Microbiology, vol. 10, no. 2, pp. 55-58, 2002.

[3] D. L. Doolan, C. Dobaño, and J. K. Baird, "Acquired immunity to Malaria," Clinical Microbiology Reviews, vol. 22, no. 1, pp. 13-36, 2009.

[4] K. Artavanis-Tsakonas, J. E. Tongren, and E. M. Riley, "The war between the malaria parasite and the immune system: immunity, immunoregulation and immunopathology," Clinical and Experimental Immunology, vol. 133, no. 2, pp. 145-152, 2003.

[5] B. M. Greenwood, A. M. Bradley-Moore, A. D. Bryceson, and A. Palit, "Immunosuppression in children with malaria," The Lancet, vol. 1, no. 7743, pp. 169-172, 1972.

[6] D. B. Whitmore, "Suppression of the immune response to heterologous erythrocytes in mice infected with Plasmodium berghei berghei," Transactions of the Royal Society of Tropical Medicine and Hygiene, vol. 66, no. 1, pp. 5-6, 1972.

[7] B. C. Urban, R. Ing, and M. M. Stevenson, "Early interactions between blood-stage Plasmodium parasites and the immune system," Current Topics in Microbiology and Immunology, vol. 297, pp. 25-70, 2005.

[8] K. Grech, K. Watt, and A. F. Read, "Host-parasite interactions for virulence and resistance in a malaria model system," Journal of Evolutionary Biology, vol. 19, no. 5, pp. 1620-1630, 2006.

[9] M. N. Wykes, X. Q. Liu, L. Beattie, et al., "Plasmodium strain determines dendritic cell function essential for survival from malaria," PLoS Pathogens, vol. 3, no. 7, article e96, 2007.

[10] H. Hofte and H. R. Whiteley, "Insecticidal crystal proteins of Bacillus thuringiensis," Microbiological Reviews, vol. 53, no. 2, pp. 242-255, 1989.

[11] P. J. K. Knight, N. Crickmore, and D. J. Ellar, "The receptor for Bacillus thuringiensis CrylA(c) delta-endotoxin in the brush border membrane of the lepidopteran Manduca sexta is aminopeptidase N," Molecular Microbiology, vol. 11, no. 3, pp. 429-436, 1994.

[12] E. Schnepf, N. Crickmore, J. Van Rie, et al., "Bacillus thuringiensis and its pesticidal crystal proteins," Microbiology and Molecular Biology Reviews, vol. 62, no. 3, pp. 775-806, 1998.

[13] S. Rojas-Hernandez, M. A. Rodriguez-Monroy, R. LopezRevilla, A. A. Resendiz-Albor, and L. Moreno-Fierros, "Intranasal coadministration of the CrylAc protoxin with 
amoebal lysates increases protection against Naegleria fowleri meningoencephalitis," Infection and Immunity, vol. 72, no. 8, pp. 4368-4375, 2004.

[14] R. I. Vázquez-Padrón, L. Moreno-Fierros, L. Neri-Bazán, G. A. de la Riva, and R. López-Revilla, "Intragastric and intraperitoneal administration of CrylAc protoxin from Bacillus thuringiensis induces systemic and mucosal antibody responses in mice," Life Sciences, vol. 64, no. 21, pp. 1897 1912, 1999.

[15] G. G. Guerrero and L. Moreno-Fierros, "Carrier potential properties of Bacillus thuringiensis CrylA toxins for a diphtheria toxin epitope," Scandinavian Journal of Immunology, vol. 66, no. 6, pp. 610-618, 2007.

[16] G. G. Guerrero, W. M. Russell, and L. Moreno-Fierros, "Analysis of the cellular immune response induced by Bacillus thuringiensis CrylA toxins in mice: effect of the hydrophobic motif from diphtheria toxin," Molecular Immunology, vol. 44, no. 6, pp. 1209-1217, 2007.

[17] S. Roetynck, M. Baratin, S. Johansson, C. Lemmers, E. Vivier, and S. Ugolini, "Natural killer cells and malaria," Immunological Reviews, vol. 214, no. 1, pp. 251-263, 2006.

[18] K. Artavanis-Tsakonas and E. M. Riley, "Innate immune response to malaria: rapid induction of IFN- $\gamma$ from human NK cells by live Plasmodium falciparum-infected erythrocytes," Journal of Immunology, vol. 169, no. 6, pp. 2956-2963, 2002.

[19] A. Z. Ge, R. M. Pfister, and D. H. Dean, "Hyperexpression of a Bacillus thuringiensis delta-endotoxin-encoding gene in Escherichia coli: properties of the product," Gene, vol. 93, no. 1, pp. 49-54, 1990.

[20] M. M. Bradford, "A rapid and sensitive method for the quantitation of microgram quantities of protein utilizing the principle of protein dye binding," Analytical Biochemistry, vol. 72, no. 1-2, pp. 248-254, 1976.

[21] M. Legorreta-Herrera, M. L. Ventura-Ayala, R. N. LiconaChavez, I. Soto-Cruz, and F. F. Hernandez-Clemente, "Early treatment during a primary malaria infection modifies the development of cross immunity," Parasite Immunology, vol. 26, no. 1, pp. 7-17, 2004.

[22] S. Campino, S. Bagot, M.-L. Bergman, et al., "Genetic control of parasite clearance leads to resistance to Plasmodium berghei ANKA infection and confers immunity," Genes and Immunity, vol. 6, no. 5, pp. 416-421, 2005.

[23] A. Shibui, N. Hozumi, C. Shiraishi, et al., "CD4 ${ }^{+}$T cell response in early erythrocytic stage malaria: Plasmodium berghei infection in BALB/c and C57BL/6 mice," Parasitology Research, vol. 105, no. 1, pp. 281-286, 2009.

[24] A. R. Rodriguez-Orozco, G. Rico Rosillo, and R. Lopez-Revilla, "The effect of Cry1Ac on human monocytes and neutrophil activation," Allergy and Clinical Immunology International, vol. 17, no. 2, pp. 64-65, 2005.

[25] Y. Nagamatsu, T. Koike, K. Sasaki, A. Yoshimoto, and Y. Furukawa, "The cadherin-like protein is essential to specificity determination and cytotoxic action of the Bacillus thuringiensis insecticidal CryIAa toxin," FEBS Letters, vol. 460, no. 2, pp. 385-390, 1999.

[26] C. F. Ockenhouse, S. Schulman, and H. L. Shear, "Induction of crisis forms in the human malaria parasite Plasmodium falciparum by $\gamma$-interferon-activated, monocyte-derived macrophages," Journal of Immunology, vol. 133, no. 3, pp. 1601-1608, 1984.

[27] T. Yoneto, T. Yoshimoto, C.-R. Wang, et al., "Gamma interferon production is critical for protective immunity to infection with blood-stage Plasmodium berghei XAT but neither NO production nor NK cell activation is critical," Infection and Immunity, vol. 67, no. 5, pp. 2349-2356, 1999.

[28] H. L. Shear, R. Srinivasan, T. Nolan, and C. Ng, "Role of IFN$\gamma$ in lethal and nonlethal malaria in susceptible and resistant murine hosts," Journal of Immunology, vol. 143, no. 6, pp. 2038-2044, 1989.

[29] F. M. Omer, J. B. de Souza, and E. M. Riley, "Differential induction of TGF- $\beta$ regulates proinflammatory cytokine production and determines the outcome of lethal and nonlethal Plasmodium yoelii infections," Journal of Immunology, vol. 171, no. 10, pp. 5430-5436, 2003.

[30] K. N. Couper, D. G. Blount, J. C. R. Hafalla, N. Van Rooijen, J. B. de Souza, and E. M. Riley, "Macrophage-mediated but gamma interferon-independent innate immune responses control the primary wave of Plasmodium yoelii parasitemia," Infection and Immunity, vol. 75, no. 12, pp. 5806-5818, 2007.

[31] M. M. Stevenson and E. M. Riley, "Innate immunity to malaria," Nature Reviews Immunology, vol. 4, no. 3, pp. 169180, 2004.

[32] R. J. Pleass, S. A. Ogun, D. H. McGuinness, J. G. J. Van De Winkel, A. A. Holder, and J. M. Woof, "Novel antimalarial antibodies highlight the importance of the antibody Fc region in mediating protection," Blood, vol. 102, no. 13, pp. 44244430, 2003.

[33] A. E. Tebo, P. G. Kremsner, and A. J. F. Luty, "Fcy receptormediated phagocytosis of Plasmodium falciparum-infected erythrocytes in vitro," Clinical and Experimental Immunology, vol. 130, no. 2, pp. 300-306, 2002.

[34] M. M. Mota, K. N. Brown, A. A. Holder, and W. Jarra, "Acute Plasmodium chabaudi chabaudi malaria infection induces antibodies which bind to the surfaces of parasitized erythrocytes and promote their phagocytosis by macrophages in vitro," Infection and Immunity, vol. 66, no. 9, pp. 4080-4086, 1998.

[35] Y. Peng, R. Kowalewski, S. Kim, and K. B. Elkon, "The role of IgM antibodies in the recognition and clearance of apoptotic cells," Molecular Immunology, vol. 42, no. 7, pp. 781-787, 2005.

[36] H. L. Shear, R. S. Nussenzweig, and C. Bianco, "Immune phagocytosis in murine malaria," Journal of Experimental Medicine, vol. 149, no. 6, pp. 1288-1298, 1979.

[37] B. D. Akanmori, S. Waki, and M. Suzuki, "Immunoglobulin $\mathrm{G}(2 \mathrm{a})$ isotype may have a protective role in Plasmodium berghei NH65 infection in immunised mice," Parasitology Research, vol. 80, no. 8, pp. 638-641, 1994.

[38] S. Waki, S. Uehara, K. Kanbe, H. Nariuch, and M. Suzuki, "Interferon-gamma and the induction of protective IgG2a antibodies in non-lethal Plasmodium berghei infections of mice," Parasite Immunology, vol. 17, no. 10, pp. 503-508, 1995.

[39] J. Langhorne, K. J. Kim, and R. Asofsky, "Distribution of immunoglobulin isotypes in the nonspecific B-cell response induced by infection with Plasmodium chabaudi adami and Plasmodium yoelii," Cellular Immunology, vol. 90, no. 1, pp. 251-257, 1985.

[40] R. A. Cavinato, K. R. B. Bastos, L. R. Sardinha, R. M. Elias, J. M. Alvarez, and M. R. D’Império Lima, "Susceptibility of the different developmental stages of the asexual (schizogonic) erythrocyte cycle of Plasmodium chabaudi chabaudi to hyperimmune serum, immunoglobulin (Ig)G1, IgG2a and $\mathrm{F}\left(\mathrm{ab}^{\prime}\right)_{2}$ fragments," Parasite Immunology, vol. 23, no. 11, pp. 587-597, 2001.

[41] L. Kedzierski, C. G. Black, A. W. Stowers, M. W. Goschnick, D. C. Kaslow, and R. L. Coppel, "Comparison of the protective efficacy of yeast-derived and Escherichia coli-derived recombinant merozoite surface protein $4 / 5$ against lethal challenge 
by Plasmodium yoelii," Vaccine, vol. 19, no. 32, pp. 4661-4668, 2001.

[42] O. Garraud, S. Mahanty, and R. Perraut, "Malaria-specific antibody subclasses in immune individuals: a key source of information for vaccine design," Trends in Immunology, vol. 24, no. 1, pp. 30-35, 2003.

[43] C. M. Snapper and W. E. Paul, "Interferon- $\gamma$ and B cell stimulatory factor-1 reciprocally regulate Ig isotype production," Science, vol. 236, no. 4804, pp. 944-947, 1987.

[44] S. Cohen, I. A. McGregor, and S. Carrington, "Gammaglobulin and acquired immunity to human malaria," Nature, vol. 192, no. 4804, pp. 733-737, 1961.

[45] A. Sabchareon, T. Burnouf, D. Ouattara, et al., "Parasitologic and clinical human response to immunoglobulin administration in falciparum malaria," American Journal of Tropical Medicine and Hygiene, vol. 45, no. 3, pp. 297-308, 1991.

[46] H. Bouharoun-Tayoun, P. Attanath, A. Sabchareon, T. Chongsuphajaisiddhi, and P. Druilhe, "Antibodies that protect humans against Plasmodium falciparum blood stages do not on their own inhibit parasite growth and invasion in vitro, but act in cooperation with monocytes," Journal of Experimental Medicine, vol. 172, no. 6, pp. 1633-1641, 1990.

[47] H. Bouharoun-Tayoun, C. Oeuvray, F. Lunel, and P. Druilhe, "Mechanisms underlying the monocyte-mediated antibodydependent killing of Plasmodium falciparum asexual blood stages," Journal of Experimental Medicine, vol. 182, no. 2, pp. 409-418, 1995.

[48] A. Ferrante, L. Kumaratilake, C. M. Rzepczyk, and J.-M. Dayer, "Killing of Plasmodium falciparum by cytokine activated effector cells (neutrophils and macrophages)," Immunology Letters, vol. 25, no. 1-3, pp. 179-187, 1990.

[49] H. Groux and J. Gysin, "Opsonization as an effector mechanism in human protection against asexual blood stages of Plasmodium falciparum: functional role of IgG subclasses," Research in Immunology, vol. 141, no. 6, pp. 529-542, 1990. 

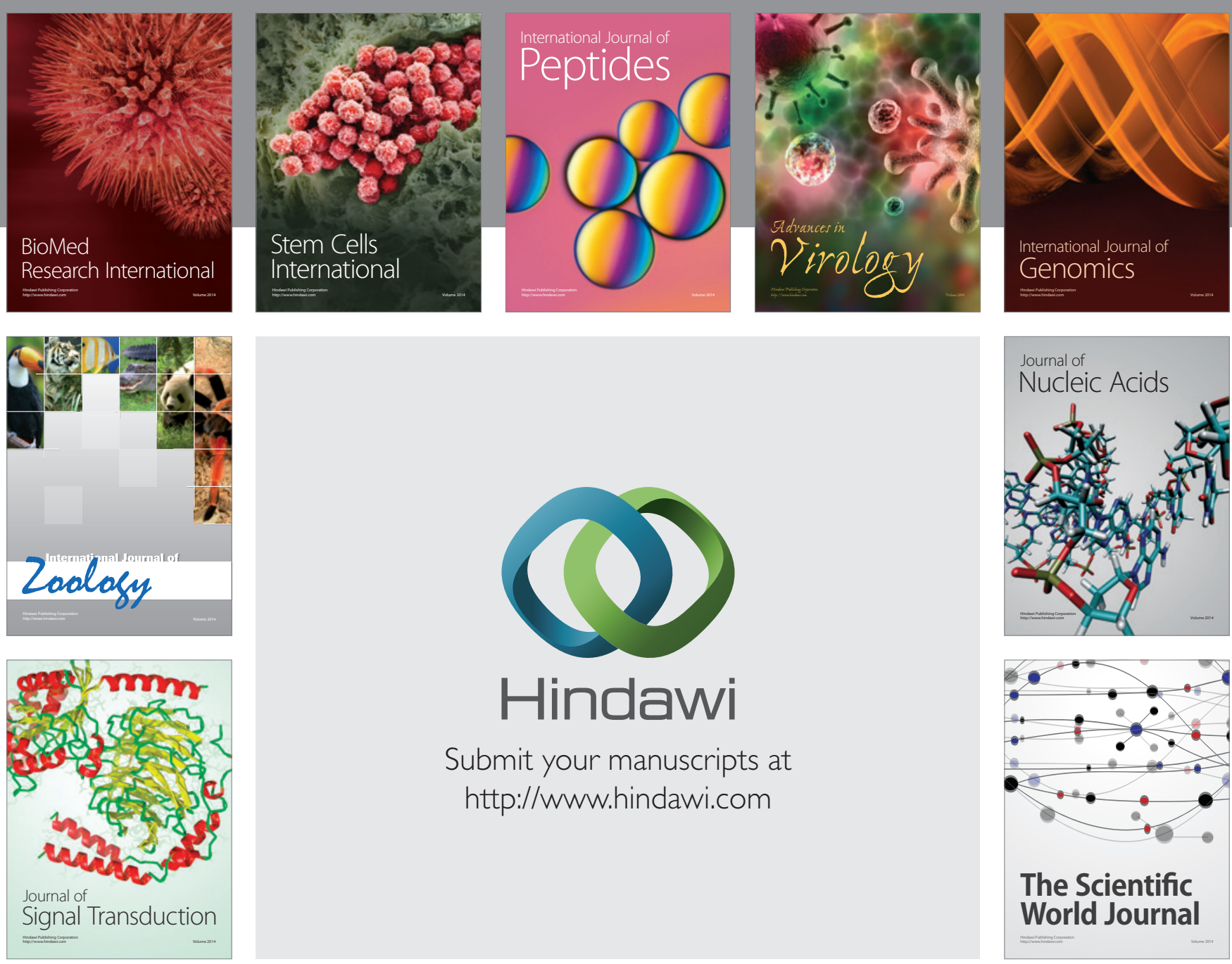

Submit your manuscripts at

http://www.hindawi.com
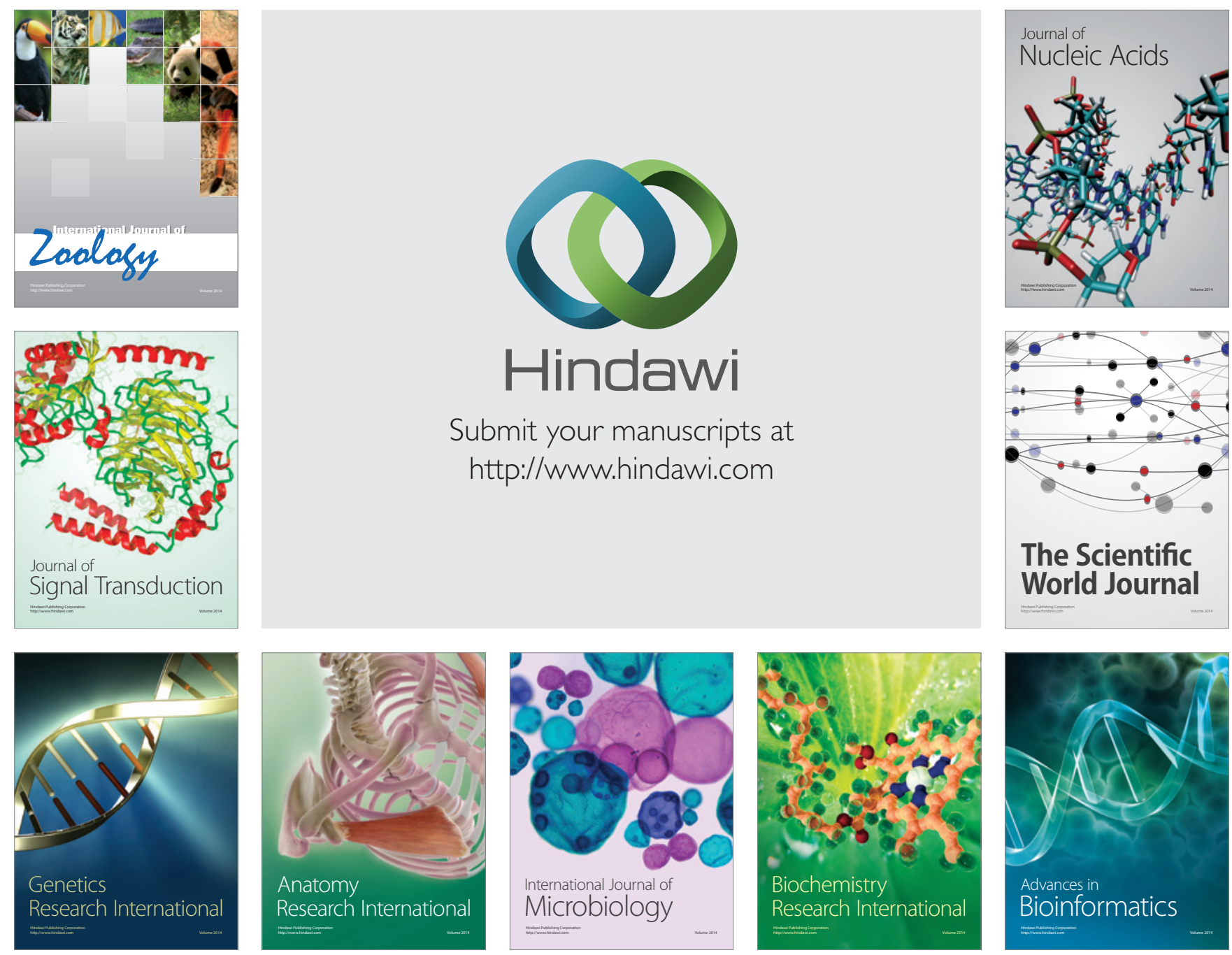

The Scientific World Journal
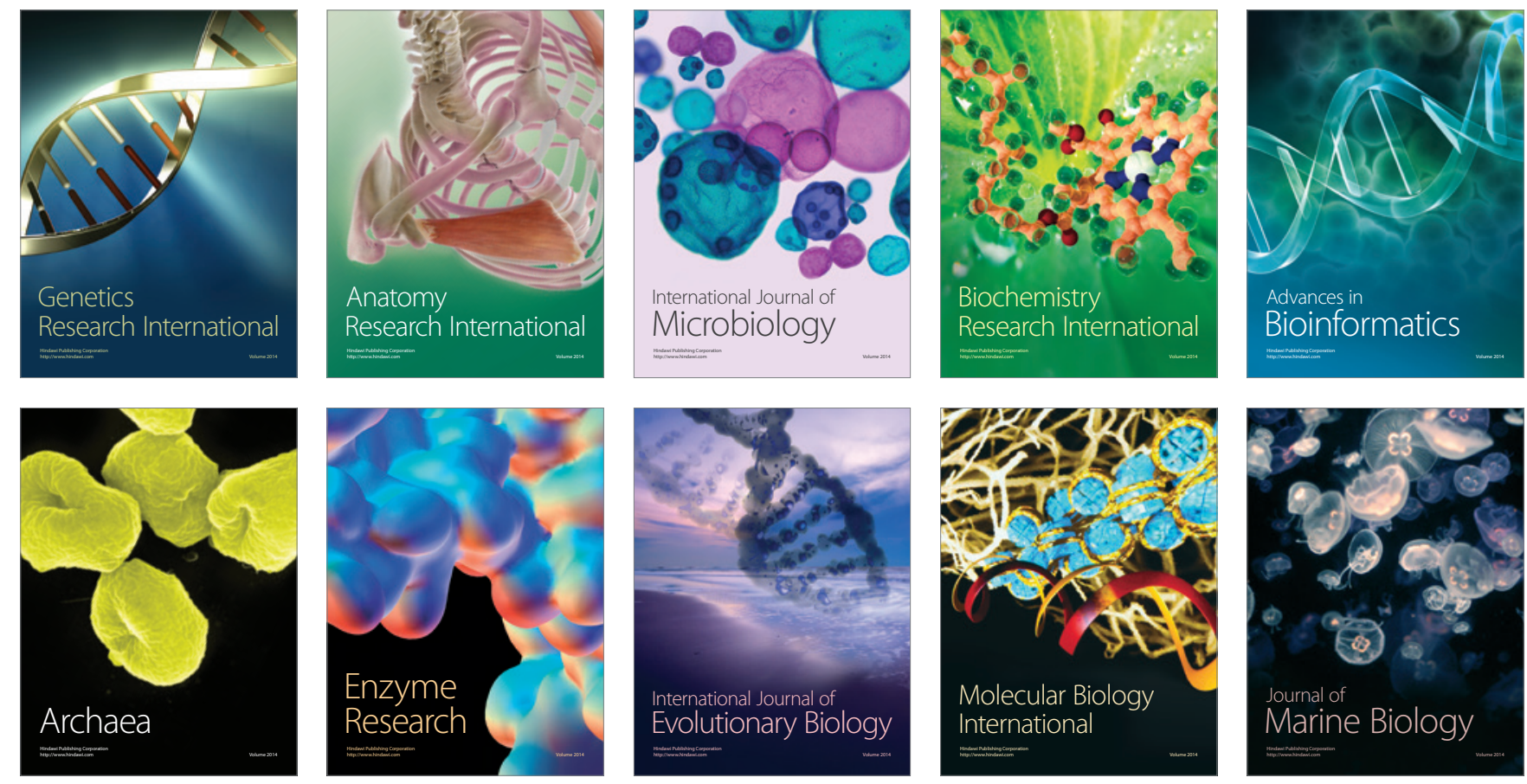